\title{
RECONFIGURAREA TIMPULUI SACRU ÎN LUMEA BRANDURILOR. DISCURS PUBLICITAR - PERSPECTIVĂ DiACRONICĂ
}

\author{
Flavia-Elena Oșan \\ Universitatea Tehnică din Cluj-Napoca \\ Centrul Universitar Nord Baia Mare, România \\ Reconfiguration of sacred time in the world of brands.
Advertising discourse - diachronic perspective
}

\begin{abstract}
In Romanian public space, the advertising discourse promoting trade names (understood as an intertextually motivated phenomenon) along with its associations and connotations reflect a set of cultural characteristics specific to Romanian consumers. By interpreting the idea of celebration as a reiteration of sacred time, advertising aims to determine consumers' purchasing behaviour by introducing in the collective mentality the idea of time for celebrations, feasts, gifts and escaping daily routine. Regardless of the target audience - religious or nonreligious -, the basic function of advertising discourse is to encourage consumers to immediately purchase a promoted product.

The article aims to analyse, from a diachronic perspective, how sacred time is reconfigured in some of the brands promoted by the Romanian media and how slogans/ advertisements build the image of Romanian culture anchored in the sacred values specific to its religious dimension. Advertising will also be analysed as a perlocutionary act, a text that persuades the receiver to purchase a particular product using sacred holidays as pretexts.

The research methodology is borrowed from semantics, stylistics, lexicology, pragmatics, economic sciences and sociology.

The corpus consists of examples selected from the Internet, shopping centres, specific magazines and advertising billboards.
\end{abstract}

Keywords: sacred time, brand, rhetoric of advertising, perlocutionary discourse.

\section{Discursul publicitar - între sacru și profan}

În zilele noastre, publicitatea contribuie la transmiterea corpusului esențial de informații referitoare la un anumit produs ori serviciu, interacționează cu receptorul și cu orizontul cultural al acestuia, având un grad ridicat de persuadare a publicului, prin impactul vizual si auditiv pe care mizează. Prin anunțuri publicitare, sloganuri și reclame, autorii își propun să creeze oportunități de promovare a produselor, comunicarea publicitară fiind un demers complex menit să evidențieze ideea de valoare. Lansarea unui produs / serviciu pe piață și echivalarea acestuia cu ideea de valoare depind nu 
doar de proprietățile sale interne, ci mai ales de calitatea prezentării lui, de strategiile de marketing utilizate de agenții numirii și de creatorii discursului publicitar, precum și de felul în care aceștia reușesc să integreze obiectele promovate în contexte ${ }^{1}$ favorabile. Unul dintre contextele favorabile exploatate la maximum de către emițătorii discursului publicitar este timpul sacru al sărbătorilor religioase, un timp reversibil ${ }^{2}$, care aduce, în fiecare an, încasări uriașe pentru firmele care aleg să pună în prim-plan produsele, empatizând cu publicul receptor, ghidându-l spre actul cumpărării, motivate de intenţia de a dărui celor dragi bucurie. Consumatorul răspunde afectiv la reclamele, anunțurile și sloganurile publicitare create cu ocazia sărbătorilor de Crăciun, un timp care inserează în mentalitatea cumpărătorilor ideea de a oferi cadouri persoanelor apropiate, de a face acte de caritate, de a-și achiziționa produse de marcă, profitând de așa-zisele „promoții unice de sărbători” sau, pur și simplu, de a-și reînnoi universul material pe fondul unei justificări de ordin spiritual. În acest sens, specialiștii din domeniul discursului publicitar afirmă că publicitatea care pune în evidență conotațiile afective ale sărbătorilor, cu siguranță, reușește să își convingă publicul spre a achiziționa un produs de marcă:

well-linked advertising arguably increases memorability, and persuades consumers to use a brand product. In particular, advertising using sentimental, feel-good, family situations can evoke warm feelings of love, belonging, family or friendship (Cartwright, McCormick, Warnaby 2016: 82).

Creatorul discursului publicitar din domeniul comercial se bazează pe tehnici persuasive bine stabilite pentru a-și converti interesul propriu în interes comun, fiind un liant între furnizorul de bunuri și servicii și publicul receptor. Modalitățile prin care se realizează persuadarea locutorului sunt: prezentarea contextului situaţional - timp, spațiu, protagoniști (alocutorul furnizor / promotor al obiectului propus spre cumpărare și locutorul client) -, cu scopul de a capta atenția receptorului, aducerea în primplan a unui produs care este menit să rezolve o problemă, descrierea atributelor pozitive ale obiectului, interpelarea publicului prin adresări directe cu ajutorul formelor de persoana a doua (singular și plural) ale pronumelor personale și construirea unei relații de cooperare între emițătorul mesajului publicitar și publicul receptor.

1 Marcel Pérennec, analizând rolul contextului lingvistic și extralingvistic în interpretarea mesajului unui discurs, afirmă faptul că: „l'interprétation en contexte joue un rôle essentiel dans l'analyse des fonctions discursives. Il s'ensuit que la compréhension d'un énoncé n'est pas un simple décodage, se bornant à enregistrer le message, mais une re-création incluant les paramètres discursif et textuel. Cette interprétation est souvent guidée par des éléments ayant valeur d'indice instructionnel” (2002: 6).

2 Mircea Eliade afirmă că „prin natura sa, Timpul sacru este reversibil, în sensul că este de fapt un timp mitic primordial readus în prezent. Orice sărbătoare religioasă, orice Timp liturgic înseamnă reactualizarea unui eveniment sacru care a avut loc într-un trecut mitic, «la începutul începuturilor». Participarea religioasă la o sărbătoare implică ieșirea din durata temporală «obișnuită» și reintegrarea în Timpul mitic actualizat de acea sărbătoare. Timpul sacru este mereu recuperabil și repetabil la nesfârșit" (1995: 41). 


\section{Discursului publicitar specific sărbătorilor - valori spirituale vs. interes material}

Discursul publicitar construit, în aparență, cu scopul de a evoca timpul sacru al sărbătorilor se prezintă ca o structură semiologică mixtă, în care mesajul scriptural și imaginile care îl estetizează au menirea de a genera semnificații info-persuasive, fiind în măsură să atragă receptorul. Aceste elemente componente ale discursului pot fi analizare nu doar ca ansamblu, ca tot unitar, ci și ca unități de sens privite în singularitatea lor. Un cuvânt care trimite simbolic la ideea de sărbătoare, o imagine bine aleasă, un nume de produs comercial creat special pentru perioada sărbătorilor și cromatica sugestivă atrag potențialii clienți, antrenând individul și comunitatea întreagă în reconfigurarea timpului sacru. Persuadarea receptorului se realizează prin utilizarea simbolurilor considerate de acesta ca fiind importante pentru timpul sacru în care se simte ancorat. Charles Larson ${ }^{3}$ definește persuasiunea din perspectiva relației stabilite între emițător și receptor, pe fondul apelului la simboluri. În realitate, valorile spirituale pe care publicitatea le promovează cu prilejul sărbătorilor religioase (bunătate, dăruire, apreciere a sinelui și a celor din jur, recunoștintă) sunt motivate de un scop material acela de a crește vânzările unui produs / serviciu. Timpul mitic al sărbătorilor este, astfel, desacralizat, fiind perceput exclusiv ca un timp al câștigurilor materiale, „a central component of the retail calendar" (McKechnie, Tynan 2006: 131) o perioadă cheie în calendarului vânzărilor pentru furnizorii de bunuri și servicii:

such positive emotions arguably have greater resonance at Christmas which is a symbolic time of love, friendship and reconciliation and importantly, closely associated with gift giving. Consequently, for retailers, Christmas is characterised by high sales volume (Cartwright, McCormick, Warnaby 2016: 83).

\section{Caracteristici ale sacrului reflectate în reclamele și anunțurile publicitare românești din perioada interbelică până în prezent}

În lucrările de specialitate, sacrul cunoaște numeroase definițiii ${ }^{4}$, fiind prezentat în opoziție cu profanul (Eliade 1995, Durkheim 1953), aflat în legătură directă cu experiența religioasă, cu timpul mitic al începuturilor: „la pensée mythique oscille entre ces deux pôles opposés: le sacré et le profane. Grâce à eux, elle structure la men-

3 Autorul consideră că persuasiunea este „crearea împreună a unei stări de identificare între sursă și receptor, ca urmare a utilizării simbolurilor" (Larson 2003: 26).

4 Mircea Eliade (1995: 41) definește timpul sacru în opoziție cu durata profană: „ca și spațiul, Timpul nu este nici omogen și nici continuu pentru omul religios. Există intervale de Timp sacru, ca de pildă timpul sărbătorilor (în cea mai mare parte periodice) și, pe de altă parte, Timpul profan, durata temporală obișnuită, în care se înscriu actele lipsite de semnificație religioasă. Între aceste două feluri de timp există, bineînțeles, o ruptură; dar, prin mijlocirea riturilor, omul religios poate „trece“ cu ușurință de la durata temporală obișnuită la Timpul sacru”. Opoziția dintre cele două concepte este remarcată și de Emile Durkheim (1953: 70), care susține că „the sacred $[\ldots]$ cannot, without losing its nature, be mixted with the profane. Any mixture or even contact profanes it $[\ldots]$, destroys its essential attributes". 
talité de l'homme traditionnel et tisse son espace georgaphique et temporel" (Boskovic 2006) și cu spațiul neomogen care trimite la momentul creării lumii:

la pensée mythique part à la recherche de l'origine du monde. L'origine est cependant le terme clé de la réflexion mythique; elle reflète le besoin vital de l'homme primitif de s'orienter dans le temps et dans l'espace, de donner sens à sa propre existence ainsi qu'à celle de l'univers entier (Ibidem).

În publicitatea românească, una dintre modalitățile prin care este reflectată latura sacră a lumii reprezintă promovarea numelor de brand și produs în contextul sărbătorilor religioase. În perioada interbelică și cea de după 1989, reclamele și anunțurile create în contextul timpului mitic readus în prezent încearcă o sacralizare a profanului, prin punerea obiectelor profane destinate vânzării într-un context sacru. Astfel, pot fi identificate, în exemplele selectate analizei, o serie de caracterisitici ale sacrului: opoziţia cu profanul, îmbinarea sacrului cu profanul - ceea ce literatura de specialitate numește contamination ${ }^{5}$-, sacrificiul și dăruirea sau implicarea în acte care scot la iveală bunătatea umană. Perioada comunistă a reprezentat un interval temporal în care sărbătorile religioase nu erau promovate în discursurile oficiale ale conducerii politice, subiecte precum Nașterea Domnului sau Învierea, fiind interzise, fapt ce a determinat dispariția de pe piață a reclamelor și anunțurile publicitare care evocau timpul sacru al sărbătorilor religioase.

\subsection{Opoziția sacru vs. profan - aspecte morfologice ale discursului publicitar}

În reclamele și anunțurile publicitare românești, opoziția sacru vs. profan este marcată prin recurența unor lexeme care marchează ieșirea din timpul obișnuit, monoton și intrarea în timpul festiv.

La nivel morfologic, se observă predilecția pentru substantivul comun sărbătoare, utilizat, de obicei, cu forma de plural, scris, uneori, cu majusculă și însoțit de prepoziții simple precum de, pentru: „Dăruiți de sărbători colecțiile de țigări și țigarete, produse superioare ale Casei Autonome a Monopolurilor Regatului României” (Fig.3), „De Sărbători - un Super Inductance. Scrieți aceasta repede pe listă, poate vede Moș Crăciun și v-aduce și Dv. un aparat Philips” (Fig. 7), „Pentru Sărbătorile Crăciunului, un flacon cu Apa de Colonia HUDNUT este un dar totdeauna binevenit” (Fig. 1), „De Sărbători, mânâncă mult și poartă S. (Skittles)”, „Tuborg Christmas Brew. Berea cu gust special de Sărbători”, „De Sărbători, sună și fă-i să zâmbească. Vodafone îți oferă mii de minute cadou la abonamente ca să le faci tuturor sărbătorile mai frumoase”, „Puterea Alintaromei ne aduce aproape de cei dragi de sărbători (Jacobs)”, „ZIZIN. Dă cu pace și de Sărbători”.

În alte contexte, sunt alese substantivele proprii care numesc sărbătorile evocate (Crăciun, Paște, Anul Nou), reactualizând un eveniment sacru, cu scopul de a

5 În accepția autorilor Russell W. Belk, Melanie Wallendorf și John F. Sherry Jr. (1989: 6), „contamination in this context means the spread of positive sacredness". 
dicta, în rândul receptorilor-clienți, actul cumpărării: „De Crăciun, fii mai bun, fii adevărat/ Spune DA, nu spune NU/ La Tuborg Christmas Brew”, „Vino la Caravana de Crăciun. Trăiește magia sărbătorilor cu Coca-Cola”, „VIVO Cluj-Napoca - un brand IMMOFINANZ. Cadou de Crăciun. Câștigă 2 x Audi A4”, „În Noul An, îndeplinește-ți toate planurile. Activează cartela Vodafone ca să reușești”, „Coresi. Bucură-te de cel mai colorat Paște alături de cei dragi”, „La Pomul de Crăciun, în căminul Dvs. va fi belșug și bucurie. (Loteria de stat pe clase)” (Fig. 8), „De Crăciun, Adesgo. Adesgo, cel mai fin și rezistent ciorap" (Fig. 6). Clișeele lingvistice de tipul structurilor de sărbători, de Crăciun, de Paşte, continuate de un discurs prin care publicul este invitat să cumpere produsul promovat (adresări directe, interpelarea receptorului, prezentarea calităților pozitive ale obiectului), se întâlnesc în ambele secvențe temporale care au cunoscut dezvoltarea publicității, utilizând ca pretext, sărbătorile religioase - perioada interbelică și cea contemporană.

Verbele la indicativ prezent sunt utilizate cu scop narativ, descriptiv sau pentru a sugera ideea unui adevăr incontestabil, susținând argumentarea: „Pentru Sărbătorile Crăciunului, un flacon cu Apa de Colonia HUDNUT este un dar totdeauna binevenit" (Fig. 1), „Puterea Alintaromei ne aduce aproape de cei dragi de sărbători (Jacobs)”, „Se poate oare dărui frumusețe? Da! Ea se află în fiecare flacon de loțiune Scherk”. Imperativul este folosit cu scopul de a iniția comunicarea directă cu publicul și de a-i influența alegerea, determinându-l să cumpere obiectul promovat: „Dăruiește celor dragi cadouri fermecate. Alege pachetele cadou de la Farmec”, „Salveaz-o pe mama de Epopeea Decorațiunilor! Anul ăsta, pune tu masa pentru ai tăi!”.

Structura reclamelor și a anunțurilor publicitare citate reflectă elasticitatea ${ }^{6}$ discursului publicitar, capacitatea de a dezvolta, într-un text elaborat, o poveste care să atragă publicul prin ineditul ei ori să exprime, într-un enunț concis, mesajul dorit de furnizorul / promotorul produsului sau al brandului.

\section{2. Îmbinarea sacrului cu profanul}

În încercarea de a scoate în evidență numele de brand sau produs, pe fondul sărbătorilor, reclamele îmbină, uneori previzibil, sacrul cu profanul, utilizând clișee lingvistice cunoscute, de tipul urărilor „Deltacon. Vă urăm Crăciun Fericit și cele mai bune gânduri pentru un An Nou plin de succes. La mulți ani”, „Franzeluța. Paște fericit pentru întreaga familie”, „Bucură-te de cel mai colorat Paște alături de cei dragi. Coresi”, al adresărilor directe către public, spre a-l determina să achiziționeze un obiect special pentru sine sau pentru ceilalți: „De Sărbători, mănâncă mult și poartă S! Skittles”, „Spring Time. Cumpără o Salată și un produs de Post și primești o Baclava din partea casei” sau al frazelor enunțiative cu caracter sentențios: „Zilele de post sunt mai savuroase cu paté Bucegi vegetal”, „Decemvrie e aci și zilele scurte se scurg repede.

6 Joseph Courtés, în lucrarea Analyse sémiotique du discours: De l'énoncé à l'énonciation (1991: 10), analizează „le phénomène dit d'élasticité du discours, qui met en jeu le rapport bien connu en linguistique: expansion vs condensation". 
Sezonul cadourilor se apropie”. În alte reclame, îmbinarea sacrului cu profanul se face într-o formă care surprinde publicul prin asocieri nebănuite de câmpuri semantice, protagoniști, scenarii, stârnind comicul: „Pot să iau pe loc un credit ING Personal și să îi ofer lui Iubi un Crăciun de vis? DA. POȚI. PE LOC. ING”, „Galeries Lafayette. Eraţi încă la mare CÂND noi ne-am gândit la problema darurilor. De fapt, am lucrat la această direcțiune când $\mathrm{Dv}$. v-ați bucurat de razele binefăcătoare ale soarelui în costumul de baie”, „KFC. Salveaz-o pe mama. De Epopeea Decorațiunilor. Anul ăsta, pune tu masa pentru ai tăi!".

Din perspectivă onomastică, numele de brand și majoritatea numelor de produse - ca elemente fundamentale în construirea discursului publicitar - îşi păstrează forma și elementele componente, fiind ancorate, în sfera profanului. Ceea ce diferă este prezentarea lor pe piață, în contextul timpului sacru al sărbătorilor. Numele de produs, numele de brand și marca înregistrată $\breve{7}^{7}$ sunt aduse împreună într-un discurs generator de sens, capabil de a insera în mentalitatea colectivă intenția de achiziționare a obiectului promovat.

Numele de brand rămâne acelaşi, indiferent de contextul în care este promovat, are rolul de a individualiza produsul și de a-l diferenția de alte obiecte similare, reprezentând „modalitatea lingvistică sub care este lansat pe piaţă produsul” (Felecan D. 2015: 20). Numele produsului dezvoltă argumentarea publicitară și contribuie la persuadarea publicului receptor în vederea cumpărării. Expresie focalizată pe scoaterea în evidență a calității obiectului și a caracteristicilor sale de bază, numele produsului devine un semn lingvistic motivat, având puternice valențe persuasive, operând ca un argument al vânzării. În cadrul sintagmei designative, se pot identifica elemente care sugerează timpul sacru. Lexeme precum sărbători, Crăciun și traducerea în limba engleză (Christmas), sintagme precum sărbătorile de iarnă, tematică de Crăciun devin părți componente ale unor nume de produse special create cu ocazia celebrării timpului sacru. Spre deosebire de perioada interbelică, în care discursul publicitar creat în perioada premergătoare sărbătorilor evidenția felul în care comunitatea autohtonă se raporta la timpul sacru, tendința actuală a societății românești este de a împrumuta simboluri și tradiţii din Occident, realizându-se o uniformizare, la nivel comercial, a produselor lansate pe piață cu ocazia sărbătorilor. Personaje precum Moș Crăciun, elfi, reni, iepurașul de Paşte nu au aparținut culturii autohtone, nefiind surprinse în reclamele perioadei interbelice, dar au fost preluate, sub efectul globalizării, identificându-se, în zilele nostre, cu spiritul sărbătorilor de Crăciun sau Paște. Industria alimentară, cea a obiectelor decorative și vestimentare lansează pe piaţă, cu ocazia sărbătorilor, nume de produse menite să atragă receptorul-client spre cumpărare. Publicul este invitat să intre în atmosfera magică a sărbătorilor, achiziționând: Bomboane de pom Milka. Christmas Candies, Ciocolată Primola -Moș Crăciun, Pulover de damă pentru sărbătorile de iarnă

7 Terhi Ainiala, Minna Saarelma și Paula Sjöblom (2016: 213) clasifică numele comerciale în brand name, trade mark și product name, analizându-le din perspectiva funcțiilor pe care le îndeplinesc în domeniul publicității, precum și legătura lor cu domeniul financiar și de marketing. 
ONLY, Pulover de damă de iarnă Christmas in Town, Pulover damă Iarna de Crăciun cu imprimeu Ren Cheap \& Chic Happy, Pulover tricotat pentru sărbători de iarnă - Cerbi / Pinguini / Moș Crăciun și Reni, Pulover cu temaică de Crăciun HOHOHO. În exemplele citate, se observă îmbinarea sacrului cu profanul prin crearea de aşa-zise „obiecte sacre”, care evocă timpul mitic al sărbătorilor. Sacralitatea acestor obiecte este una artificială, întrucât nu a fost obținută în urma unor ritualuri de sfințire, ci a fost dată de numele produsului sau de reprezentarea materială a unor personaje asociate spiritului sărbătorilor (Moș Crăciun, reni, cerbi, brad). Ceea ce studiile de specialitate numesc contaminarea sacrului cu profanul se explică prin existența unor obiecte sfințite „objects blessed though sacred rituals are thus said to be contaminated with sacredness", ,possesions of sacred persons become venerated icons because they are contaminated with sacredness" (Belk, Wallendorf, Sherry Jr. 1989: 6). În domeniul comercial, obiectele aparţin lumii profane, rămând integrate în ea, nefiind supuse niciunui ritual de binecuvântare, ci prezentate într-un context care evocă sacrul, ele contribuie la creșterea numărului vânzărilor. În acest sens, furnizorii profită de un moment în care mentalitatea colectivă își îndreaptă atenția spre reactualizarea unor evenimente sacre, oferind impresia că vin în sprijinul consumatorului și empatizează cu acesta.

\subsection{Sacrificiul}

Ideea de sacrificiu, interpretată ca metodă de comunicare a omului cu instanța divină (în literatura religioasă), este exploatată în domeniul comercial din spaţiul românesc de către furnizorii care lansează și promovează pe piață produse de post. Profitând de perioada postului dinaintea sărbătorilor, furnizorii aduc în prim-plan produse destinate, în principiu, omului religios. Dacă în țările occidentale, acestea sunt prezentate sub denumiri de produse vegetariene sau vegan, în România, este preferată sintagma „de post” - cu trimitere la sacrificiul biblic de abținere de la produse de proveniență animală în perioada premergătoare marilor sărbători.

Postul - ca transpunere a ideii de sacrificiu ${ }^{8}$ in acțiune umană - este exploatat în domeniul comercial prin crearea unor nume de produse sugestive pentru perioada premergătoare unui eveniment sacru. În acest sens, impactul sărbătorilor asupra componentei onomastice a numelor de produse comerciale se traduce prin apariția și lansarea pe piață a unor nume de produse care adaugă, la numele inițial, sintagme nominale precum „de post” sau „produs de post”: „Vel Pitar. Cozonac de post”, „Super Mama. Ciorbă de fasole boabe de post”, „Croissant Gigant. Produs de post”, „Romana. Ciocolată de post”, „Paté Mandy. Produs de post”, „Joe - de post”, „Vel Pitar. Mini Pretzel. Produs de post"'.

8 Belk, Wallendorf și Sherry (1989: 7) definesc sacrificiul ca „an act of abnegation and submission, sacrifice establishes communication with the sacred by purifying and preparing the sacrificer. [...] Sacrifice can involve ascetism, fasting, sexual abstinence".

9 Exemplele citate aparțin - ca interval termporal - contemporaneității. 


\subsection{Dăruirea - sacralization through Gift-Giving ${ }^{10}$ - coordonate lexico- semantice și pragmalingivstice ale discursului publicitar de sărbători}

Sacralizarea profanului prin intermediul obiectelor cumpărate cu scopul de a fi oferite celorlalți este un fenomen des întâlnit în reclamele și anunțurile publicitare care promovează produse comerciale de sărbători. Bazându-se pe construirea relației dintre „tu” și „ceilalți”, publicitatea invită publicul să cumpere pentru a dărui. Majoritatea exemplelor selectate își construiesc discursul prin adresare directă cu ajutorul verbelor și pronumelor la persoana a doua, singular / plural, invitând fiecare individ să achiziționeze un obiect, pentru a-l oferi celorlalți. Destinatarul cadoului este inclus în discursul publicitar prin utilizarea unor apelative de tipul: „cei dragi”, „tuturor”, „celorlalți”, „ai tăi”. Consumatorii sunt invitaţi să cumpere, spre a dărui celorlalți o bucurie, având impresia că, în acest fel, pot transforma actul cumpărării într-o experiență transcedentală. Astfel, cu ocazia sărbătorilor, societatea de consum - profund ancorată în profan - devine o societate a consumului de sacru. Consumatorii de sacru sunt persuadați să cumpere obiecte profane, materiale, spre a le transfera într-un context sacru în care, pe lângă valoarea lor materială, vor deține și o valoare spirituală.

Analizând exemplele din corpusul selectat, la nivel lexico-semantic se observă:

- repetiția lexemului dar și a sinonimului acestuia - cadou, precum și perechea de sinonime a dărui / a oferi, elemente prezente în reclamele din perioada interbelică și cele din contemporaneitate: „Pentru Sărbătorile Crăciunului, un flacon cu Apa de Colonia HUDNUT este un dar totdeauna binevenit”, „Dăruiți de Sărbători colecțiile de țigări și țigarete, produse superioare ale Casei Autonome a Monopolurilor Regatului României”, „Dăruiți frumusețe! Se poate oare dărui frumusețe? Da! Ea se află în fiecare flacon de loțiune Scherk. Dăruiți un flacon de loțiune Scherk și veți dărui frumusețe pentru mai multe săptămâni” 11 , „Dăruiește celor dragi cadouri fermecate. Alege pachetele cadou de la Farmec”, „Pot să iau pe loc un credit ING și să îi ofer lui Iubi un Crăciun de vis? DA. POȚI. PE LOC. ING”12.

- câmpul semantic al cuvintelor care denumesc relaţii interumane (familie, prietenie): „Coresi. Bucură-te de cel mai colorat Paște alături de cei dragi”, „Franzeluța. Paște fericit pentru întreaga familie”, „Gerovital. Dăruiește celor dragi cadouri fermecate!”, „Galeries Lafayette: Orice fel de cadouri pe care imaginația le poate născoci, cadouri care încântă copilașii, care înveselesc inimile celor dragi, care cimentează prietenia, toate au fost comandate din timp și sunt acum în raioanele lor, așteptând vizita D-voastră” (Fig. 2), „Salveaz-o pe mama. De Epopeea Decorațiunilor. Anul ăsta, pune tu masa pentru ai tăi”.

- câmpul semantic al cuvintelor care exprima stări sufletești (bucurie, pace

10 Sintagma aparține autorilor Russel W. Belk, Melanie Wallendorf și John F. Sherry Jr (1989: 17).

11 Exemplele citate aparțin perioadei interbelice.

12 Exemplele sunt selectate din reclamele existente pe piață la ora actuală. 
interioară): „Galeries Lafayette: [...] cadouri care încântă copilașii, care înveselesc inimile celor dragi [...]”, , ,Vodafone. De Sărbători, sună și fă-i să zâmbească”, ,ZIZIN. Dă cu pace și de sărbători!”.

La nivel pragmalingvistic, în structura discursului publicitar creat cu ocazia sărbătorilor religioase, în domeniul comercial, se pot observa elementele situației de comunicare definite de Roman Jakobson (1963: 213-220):

- emițătorul (furnizorul sau promotorul produsului / brandului) care anticipează universul de așteptare al receptorilor, inițiază comunicarea publicitară și îi promovează mesajul, adresându-se unui public țintă bine definit: indivizii care susțin actele de caritate efectuate în preajma sărbătorilor, care oferă cadouri persoanelor apropiate şi nu numai, simțindu-se, astfel, ancorați în timpul sacru;

- canalul de comunicare (oral și / sau scris), influențat de suportul material ales de furnizor pentru a-și promova numele de brand / produs (anunț publicitar, reclamă);

- mesajul se prezintă sub forma unui text multimodal care apelează la text și imagine pentru a contura în mentalitatea colectivă ideea de a cumpăra spre a dărui mai departe;

- codul prin care emițătorul interacționează cu receptorul este verbal, utilizându-se limba română, în combinație cu lexeme din limba engleză;

- prezența receptorului în textul publicitar este semnalată de către autorii discursului prin pronume și verbe la persoana a doua, adresări directe, verbe la imperativ.

Reținem, pentru exemplificare, câteva anunțuri publicitare de sărbători - perioada interbelică:

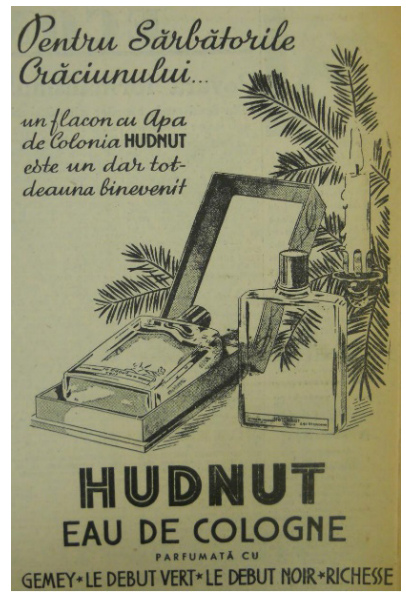

Fig. 1

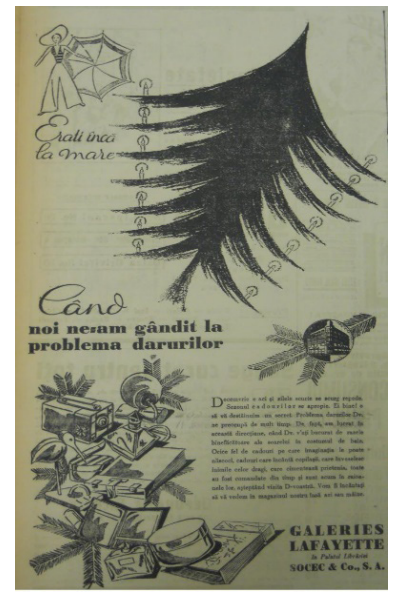

Fig. 2

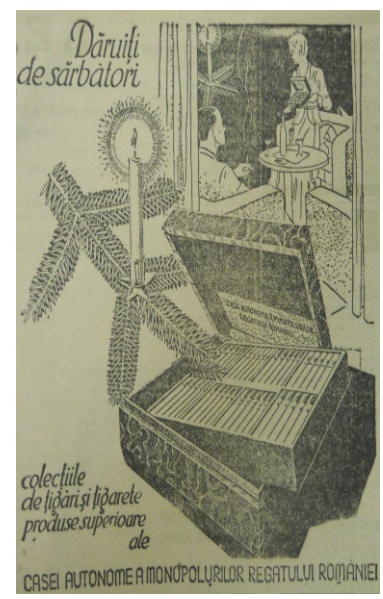

Fig. 3 


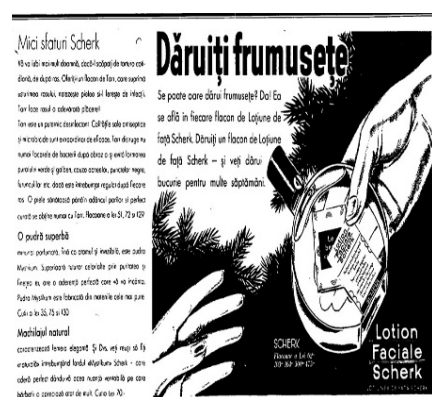

Fig. 4

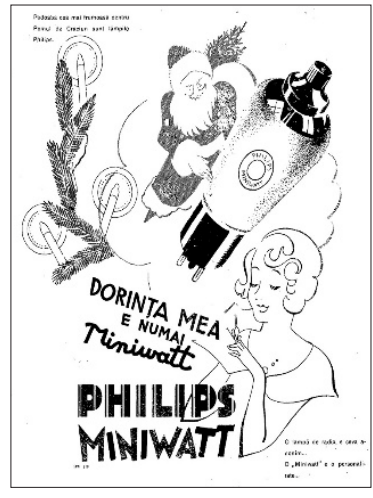

Fig. 5

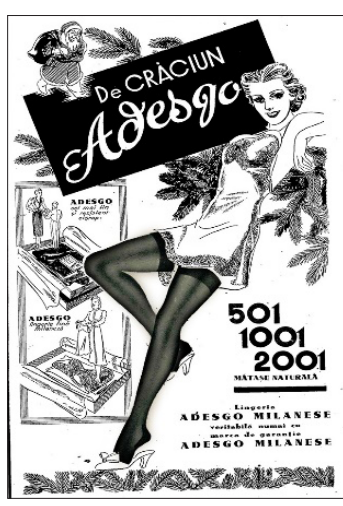

Fig. 6

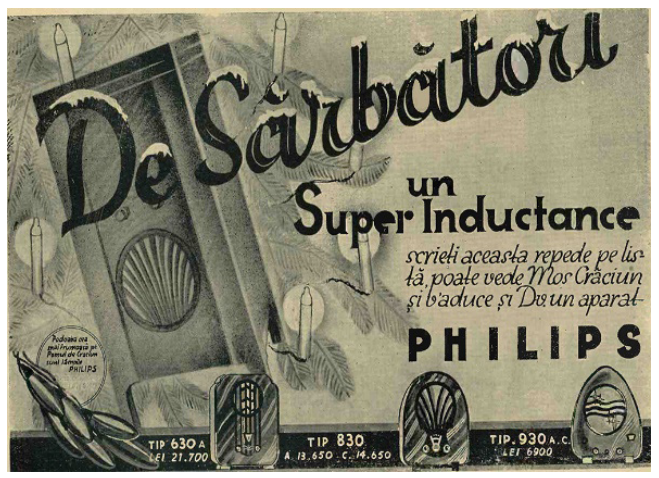

Fig. 7

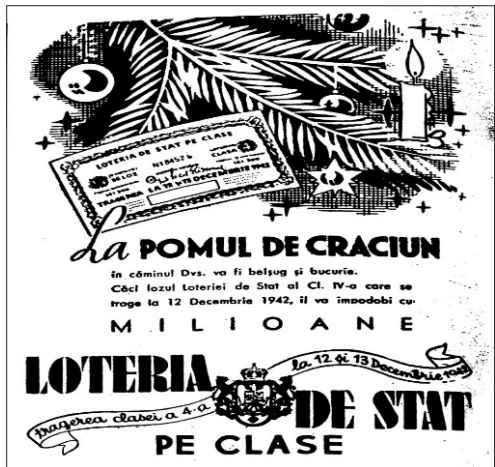

Fig. 8

Pentru a susține argumentarea noastră, redăm, în continuare, câteva anunțuri publicitare și reclame de sărbători din contemporaneitate. Spre deosebire de anunțurile publicitare din perioada interbelică, cele din zilele noastre acordă o mai mare importanță elementului iconic, în reprezentarea spiritului sărbătorilor. Elementul iconic ${ }^{13}$ este esențial în promovarea unui produs, întrucât o imagine publicitară sugestivă conduce receptorul spre referentul ei și intră mai ușor în memoria colectivă: „visual expression is playing a vital role in various aspects of our daily life. Unlike in the past where language used to be in the central position, now the interplay of text, image, gesture or even music is becoming the mainstream" (Chunyu, Mengxi 2016: 31).

13 Din perspectiva Școlii lui Pierce și a discipolilor lui (Morris, Moles), elementul iconic stabilește o asemănare cu obiectul, „posedă proprietățile indiciilor lui” (Morris 1946: 115). 


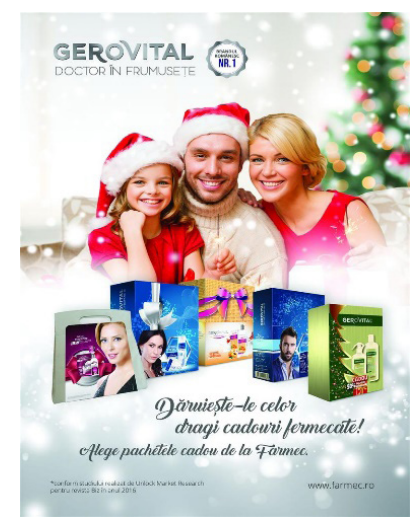

Fig. 9

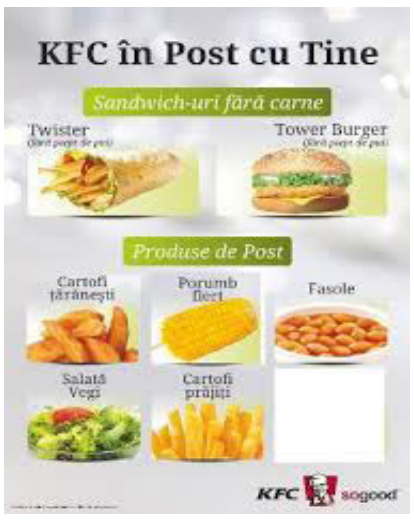

Fig. 10

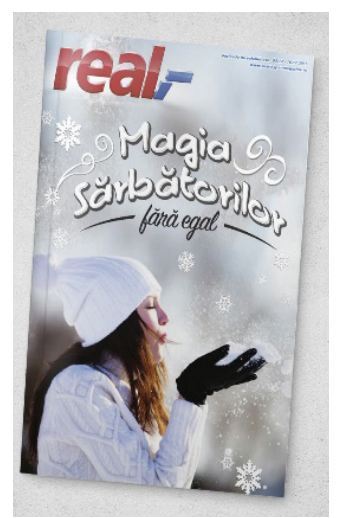

Fig. 11

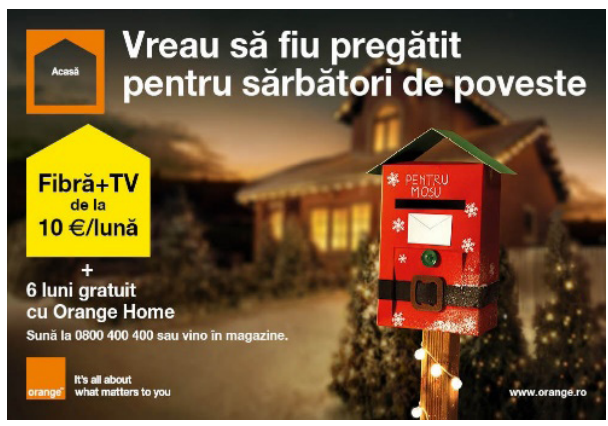

Fig. 13

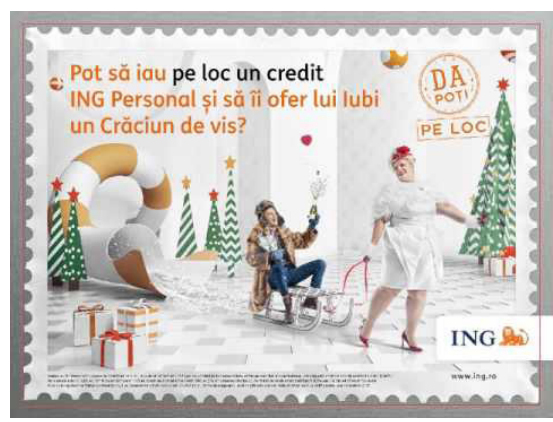

Fig. 14

\section{Numele comerciale și industria consumului de sacru}

În zilele noastre, timpul sacru al sărbătorilor, al rugăciunii și al liturghiei este reflectat și în numele de branduri și produse destinate bisericii: vinul ${ }^{14}$ utilizat în timpul liturghiei, veșmintele preoțești și alte obiecte de cult.

Numele de vinuri care dețin o simbolistică religioasă pot fi clasificate în:

- nume de vinuri care evocă nume de sfinți și sărbătorile în cinstea acestora: Vin Sfântul Gheorghe, Vin Sfinții Petru și Pavel, Vin Sfântul Nicolae, Vin Sfântul Andrei, Vin Sfânta Ana, Vin Sfânta Maria, Vin Sfinții Mihail și Gavril, Vin Sfinții Constantin și Elena;

14 „Considerat încă din religiile politeiste ca «băutură a zeilor», vinul va străbate întreaga cultură religioasă, din Vechiul Testament până la momentul Cinei celei de Taină, fiindu-i circumscrisă o valoare sacru-simbolică (prezența vinului în toate «riturile de trecere»" (Munteanu Siserman 2015: 139). 


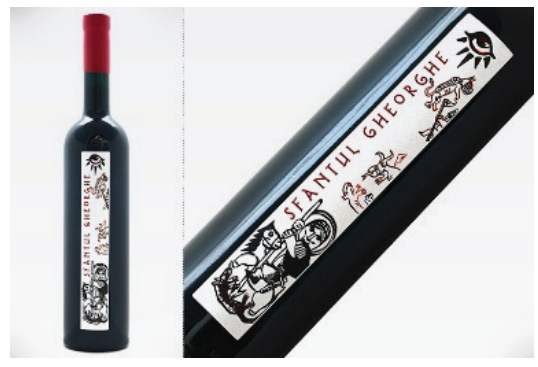

Fig. 15

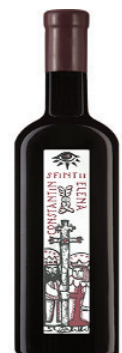

Fig. 16

- nume de vinuri care evocă timpul sacru al liturghiei: Vin Liturgic, Vin liturgic Milostivire, Vin pentru Sfânta Liturghie;

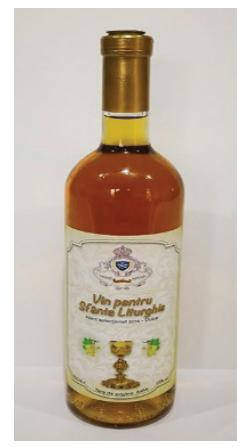

Fig. 17

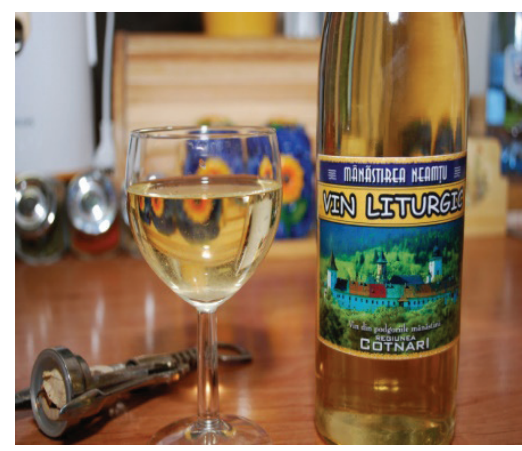

Fig. 18

- nume de vinuri care evocă instanța divină: Wine of God, Via Domnului.

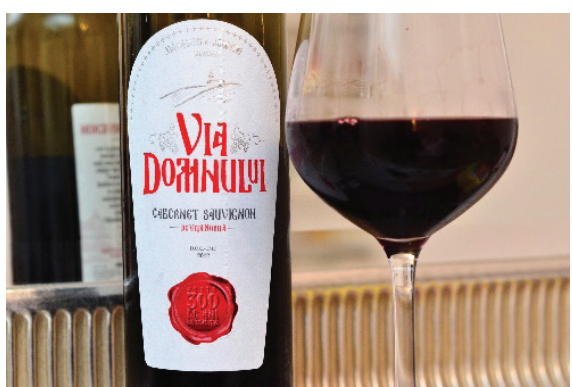

Fig. 19

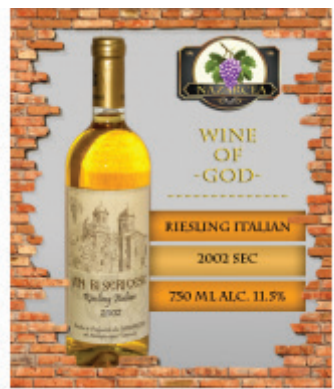

Fig. 20

La nivel onomastic, numele de firme care produc articole vestimentare și obiecte de cult bisericesc pot fi alcătuite din: 
- toponime cu valoare simbolică pentru comunitatea creștină: Emaus $(S R L)^{15}$, Bizanticons ${ }^{16}$;

- oronime: Athos $(S R L)^{17}$;

- antroponime: Jugănaru Art, Vladiana (SRL), (AF) Sandu Florin, Ciobanu Irina Valentina $(A F)^{18}$;

- nume proprii formate din substantive comune prin antonomază: Candela Criscom (SRL), Vesminte (SRL), SC Icoane Pictate (SRL), SC Icoana Bizantină (SRL), SC Vitralii Design (SRL), SC Eikon SRL ${ }^{19}$;

- nume proprii care desemnează instanța divină: SC Trinity Company SRL.

\section{Concluzii}

Bazată pe interacțiunea dintre componenta verbală și cea vizuală, publicitatea românească din perioada interbelică și din contemporaneitate evocă timpul sacru al sărbătorilor, scoate în evidență importante trăsături ale sacrului (opoziția cu profanul, îmbinarea sacrului cu profanul, sacrificiul și altruismul), având ca principal obiectiv nu promovarea valorilor spirituale și reactualizarea evenimentelor sacre, ci creșterea numărului de vânzări și a profitului material pe care furnizorii îl pot obține, promovându-și produsele în contextul sărbătorilor religioase.

Publicitatea creată cu ocazia sărbătorilor religioase exploatează trăirile afective ale omului religios, acestea devenind puncte țintă în elaborarea strategiilor de marketing.

\section{Bibliografie}

Ainiala, T., M. Saarelma și P. Sjöblom. 2012. Names in Focus: An Introduction to Finnish Onomastics. L. Pearl (trad.). Helsinki: Finnish Literature Society.

Belk, R., M. Wallendorf și John F. Sherry Jr. 1989. The Sacred and the Profane in Consumer Behaviour: Theodicy on the Odyssey. The Journal of Consumer Research 16 (1): 1-38.

Boskovic, S. 2006. Le temps et l'espace - de la conscience mythique à la conscience phénoménologique. Mémoire(s), identité(s), marginalité(s) dans le monde contemporain. Cahiers du MIMMOC 2/2006: Identité et territoire. https://mimmoc.revues.org/204 (accesat în august 2017).

Cartwright, J., H. Mccormick și G. Warnaby. 2016. Consumers' emotional responses to the Christmas TV advertising of four retail brands. Journal of Retailing and Consumer Services 29: 82-91.

Chunyu, H., L. Mengxi. 2016. A Social Semiotic Analysis of Air France's Print Advertisements. International Journal of English Linguistics 6: 30-40.

15 Numele face trimitere la localitatea din Ţara Sfântă pe drumul căreia Iisus Hristos s-a alăturat lui Luca și Cleopa în prima zi a învierii Sale.

16 Nume format din toponimul Bizanț (Imperiul Roman de Răsărit, spațiu semnificativ pentru religia ortodoxă) + icons (traducerea în limba engleză a cuvântului icoană).

17 Munte situat în nord-estul Greciei, cunoscut pentru numeroasele mănăstiri și schituri ortodoxe construite în acea regiune.

18 Exemplele selectate redau numele fondatorilor sau al proprietarilor firmei.

19 În limba greacă, eikón înseamnă „imagine, reprezentare”. 
Courtés, J. 1991. Analyse sémiotique du discours: De l'énoncé à l'énonciation. Paris: Hachette Supérieur.

Durkheim, E. 1953. Sociology and Philosophy. D.F. Pockock (trad.). London: Cohen \& West.

Eliade, M. 1995. Sacrul și Profanul. B. Prelipceanu (trad.). București: Humanitas.

Felecan, D. 2015. Numele de brand: repere de analiză. În Proceedings of the Third International Conference on Onomastics "Name and Naming”. Conventional/ Unconventional in Onomastics, O. Felecan (ed.), 17-24. Cluj-Napoca: Editura Mega, Argonaut.

Jakobson, R. 1963. Éssais de linguistique générale. Paris: Ed.Minuit.

Larson, Ch. U. 2003. Persuasiunea - Receptare și responsabilitate. Odette Arhip (trad.). Iași: Polirom.

McKechnie, S. și C. Tynan. 2006. Social meanings in Christmas consumption: an exploratory study of UK celebrants' consumption rituals. Journal of Consumer Behaviour 5 (2): 130-144.

Morris, Ch. 1945. Signs, Language and Behaviour. New York: Prentice Hall.

Munteanu Siserman, M. 2015. Nume și simțuri: corespondențe semantice în configurații denominative. Cluj-Napoca: Editura Mega, Argonaut.

Pérennec, M. 2002. Sur le texte. Énonciation et mots du discours en allemand. Lyon: Presses Universitaires de Lyon. 